\title{
Intraosseous generation of heat during guided surgical drilling: an ex vivo study of the effect of the temperature of the irrigating fluid
}

\author{
Kristof Boa ${ }^{\mathrm{a}, *}$, Ibrahim Barrak ${ }^{\mathrm{b}, 1}$, Endre Varga Jr ${ }^{\mathrm{d}}$, Arpad Joob-Fancsaly ${ }^{\mathrm{c}}$, \\ Endre Varga ${ }^{\text {a }}$, Jozsef Piffko ${ }^{b}$ \\ ${ }^{a}$ University of Szeged, Department of Traumatology, Semmelweis u. 6., Szeged, H-6725, Hungary \\ ${ }^{\mathrm{b}}$ University of Szeged, Department of Oral and Maxillofacial Surgery, Kalvaria sgt. 57., Szeged, H-6725, Hungary \\ ${ }^{c}$ Semmelweis University, Department of Oral and Maxillofacial Surgery, Maria u. 52., District VIII., Budapest., H-1085, Hungary \\ ${ }^{d}$ DicomLAB Kft., Pulz u. 46/B., Szeged, H-6724, Hungary \\ Accepted 7 June 2016
}

\begin{abstract}
We measured the rise in the intraosseous temperature caused by freehand drilling or drilling through a surgical guide, by comparing different temperatures of irrigation fluid $\left(10^{\circ} \mathrm{C}, 15^{\circ} \mathrm{C}\right.$, and $\left.20^{\circ} \mathrm{C}\right)$, for every step of the drilling sequence (diameters $2.0,2.5,3.0$, and $\left.3.5 \mathrm{~mm}\right)$ and using a constant drilling speed of $1200 \mathrm{rpm}$. The axial load was controlled at $2.0 \mathrm{~kg}$. Bovine ribs were used as test models. In the guided group we used 3-dimensional printed surgical guides and temperature was measured with a thermocouple. The significance of differences was assessed with the Kruskal-Wallis analysis of variance. Guided drilling with $10^{\circ} \mathrm{C}$ irrigation yielded a significantly lower increment in temperature than the $20^{\circ} \mathrm{C}$-guided group. When compared with the $20^{\circ} \mathrm{C}$ freehand group, the reduction in temperature in the $10^{\circ} \mathrm{C}$ guided group was significantly more pronounced at all diameters except $3.5 \mathrm{~mm}$. Finally, when the $10^{\circ} \mathrm{C}$-guided group was compared with the $15^{\circ} \mathrm{C}$ groups, the temperature rise was significantly less at 2.5 and $3.0 \mathrm{~mm}$ than with the guided technique, and at $3.0 \mathrm{~mm}$ compared with the freehand technique. We suggest that the use of $10^{\circ} \mathrm{C}$ pre-cooled irrigation fluid is superior to warmer fluid for keeping temperature down, and this reduces the difference between guided and freehand drilling.
\end{abstract}

(C) 2016 The British Association of Oral and Maxillofacial Surgeons. Published by Elsevier Ltd. All rights reserved.

Keywords: Irrigation fluid; Implants; Guided surgery; Drilling guide; Temperature; Bone drilling

\section{Introduction}

Keeping bony trauma to a minimum during preparation of the bed of an implant permits optimal conditions for osseointegration, which plays a key part in primary healing and so contributes to the long term success of dental implants. ${ }^{1}$

\footnotetext{
* Corresponding author. Tel.: +36204353329. Fax: +3662545531 .

E-mail addresses: boa.kristof@gmail.com (K. Boa),

barrakibrahim@gmail.com (I. Barrak).

${ }^{1}$ Fax: +3662561340.
}

Drilling of bone is a common technique used in various types of surgery, and the generation of heat and associated mechanical damage during rotary cutting can influence the process of osseointegration. Previous studies have shown that necrosis can develop when the temperature during osteotomy exceeds $47^{\circ} \mathrm{C} .{ }^{2,3}$

In recent years progress in the field of guided surgery has accelerated, and static surgical guides are now common devices. ${ }^{4,5}$ Misir et al. found that when a guide is used during drilling the increase in temperature is greater than when the implant site is prepared conventionally. ${ }^{6}$ In another study, the 
difference between the guided flapless and flap techniques in terms of increase in temperature did not differ significantly. ${ }^{7}$ Two other studies have shown that the heat caused by drilling in a surgical guide stays within the safe zone. ${ }^{8,9}$

To overcome thermal damage irrigation is essential ${ }^{10,11}$ and, in particular, cold irrigation fluid has been found to be superior to fluid warmed to room temperature in minimising rises. $^{12,13}$

However, to the best of our knowledge there has been no research into the use of irrigation solutions at different temperatures together with a surgical guide. We have previously found that with a higher drilling speed (1200 rpm) the rise in temperature could be near the necrotic threshold, so we wished to know if the use of saline solutions at various temperatures during guided surgical drilling at a speed of $1200 \mathrm{rpm}$ would result in smaller rises.

\section{Material and methods}

Bovine ribs were used, because of their favourable thermophysical and anatomical characteristics. Davidson and James had already shown that bovine ribs are thermally isotropic, whilst their conductivity is identical to that of human mandible. ${ }^{14}$

The densities of the cortical and cancellous bone of bovine ribs have been shown to be analogous to those of human bone as measured by computed tomography, ${ }^{15}$ and the study by Katranji et al. concluded that the mean edentulous and dentate cortical thickness falls between 1 and $2 \mathrm{~mm}$, and 1.6 and $2.0 \mathrm{~mm}$, respectively. ${ }^{16}$ The thicknesses of our segments of bovine rib were within the same range. Sener et al. concluded that the increase in temperature was greater in cortical bone than in the deeper parts of the drilling cavity, ${ }^{12}$ which has been confirmed by other studies. ${ }^{17,18}$ Specimens of bovine rib bone with a cortical thickness similar to that of the human mandible were therefore used, and the measurements (which were made in the cortical layer of the bone) described the peak temperature during drilling.

Every specimen was taken from the same animal, and they were all stored at $-10^{\circ} \mathrm{C}$ in normal saline solution between the experiments, as described by Sedlin and Hirsch. ${ }^{19}$ The animal was not killed for the experiment.

Our measurements were designed to replicate the rise in temperature during preparation of an implant site throughout a full drilling sequence $(2.0,2.5,3.0$, and $3.5 \mathrm{~mm}$ drilling), using a standard drilling speed $(1200 \mathrm{rpm})$ and a standard quantity of external irrigation solution. The factors that were varied were whether the drilling was freehand or guided, and the temperature of the irrigating saline: $20^{\circ} \mathrm{C}, 15^{\circ} \mathrm{C}$, or $10^{\circ} \mathrm{C}$. Each group was defined by the depth of drilling, the technique, and the temperature of the irrigant. Twenty-four groups were studied, and 20 measurements made in each group. In the groups in which guided surgery was evaluated we used a model surgical guide that had $2 \times 5$ guiding holes with metal sleeves (Fig. 1) and four holes for the fixing pins.
Entry points for the freehand groups were marked on the surface of the specimens with the help of the surgical guide.

$\mathrm{K}$-type thermocouples were used to measure temperature with a connecting measurement device (Holdpeak-885A, Holdpeak, China). The thermocouples were consistently placed into a well that had been prepared with a start drill $2.0 \mathrm{~mm}$ in diameter and a depth of $1.8 \mathrm{~mm}$ (so that we could make sure that the depth of the cavity never exceeded the cortical layer). The thermocouple was placed so that it touched the lateral bony wall of the cavity that was closest to the implant bed to be drilled and then tightly filled with bone chips derived from specimens of rib from the same animal, and the hole was thoroughly sealed with plasticine to maintain adequate insulation (Fig. 2).

Measurement cavities were positioned directly underneath the metal sleeve of the surgical guide, $1.75 \mathrm{~mm}$ horizontally from the $2.0 \mathrm{~mm}$ drilling canal, $1.5 \mathrm{~mm}$ from the $2.5 \mathrm{~mm}$ drilling canal, $1.25 \mathrm{~mm}$ from the $3.0 \mathrm{~mm}$ drilling canal, and $1.0 \mathrm{~mm}$ from the $3.5 \mathrm{~mm}$ (final) drilling canal (Fig. 2). To ensure comparable results, the measurement cavities were prepared in the same positions for the freehand groups. The precise position of the measurement cavities was calculated from a 3-dimensionally printed guide, which could be anchored with pins in the same position as the model surgical guide (Fig. 1).

A constant axial pressure was maintained throughout the procedure, and the axial load was controlled at $2.0 \mathrm{~kg}$. Tehemar et al. had concluded that $2.0 \mathrm{~kg}$ can be considered as low hand pressure, ${ }^{20}$ and this correlated with the observations of a recently-published systematic review by Möhlhenrich et al. which confirmed that $2.0 \mathrm{~kg}$ is the most extensively used axial load. ${ }^{21}$ A bench drill (Bosch PBD 40, Bosch, Germany) with adjustable speed was used for drilling.

Before the measurements were made the specimens of bone were warmed to $37^{\circ} \mathrm{C}$ in saline tanks, and we drilled only when the baseline temperature had fallen between $35^{\circ} \mathrm{C}$ and $37^{\circ} \mathrm{C}$. Standard, constant, external irrigation generated by a commercially-available physiodispenser surgical unit (W\&H Implantmed SI-923, W\&H, Austria) was applied through a standard cannula (W\&H, Austria) attached to the drilling machine and directed to the drill bit at a flow rate of $105 \mathrm{ml} /$ minute. The temperature of the irrigation fluid was either $20(1)^{\circ} \mathrm{C}$ (room temperature), or 15 (1) ${ }^{\circ} \mathrm{C}$, or 10 (1) ${ }^{\circ} \mathrm{C}$. Before each measurement the temperature of the saline solutions was checked with an infrared thermometric device (Holdpeak-320, Holdpeak, China).

The full experiment is shown in Fig. 3. Each one was made (and the full apparatus stored) in the same air-conditioned room at a temperature of $20(1){ }^{\circ} \mathrm{C}$. Temperature rises (peak temperature minus baseline temperature) were analysed statistically with the help of Statistica for Windows 10.0 (StatSoft, Tulsa, OK, now Dell Software Group, CA, USA). As the Shapiro-Wilk test indicated that the distributions were skewed, we used the Kruskal-Wallis analysis of variance for comparisons between groups. 

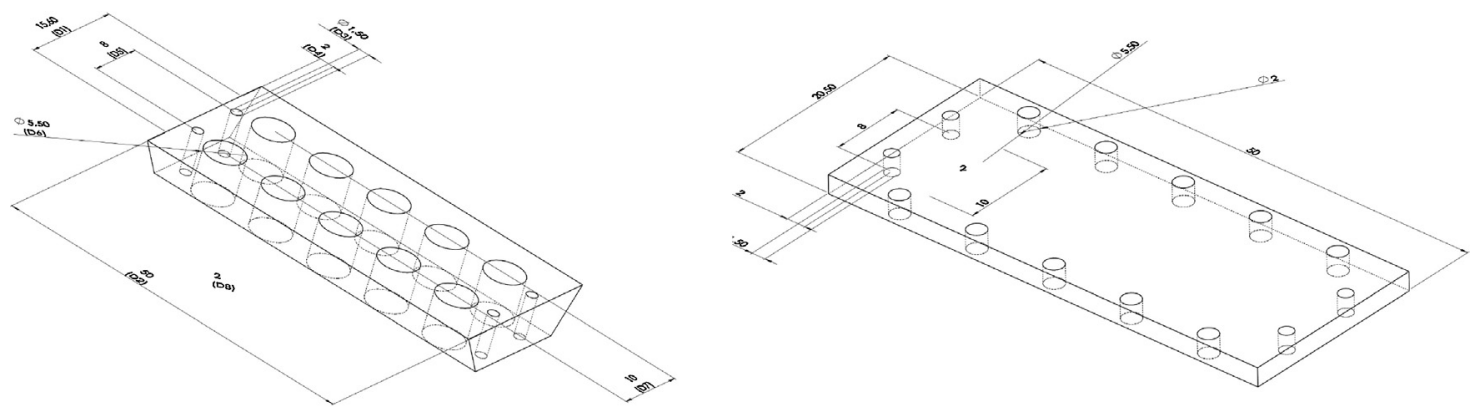

Fig. 1. The 3-dimensional printed surgical drilling guide (left) and the 3-dimensional printed guide to help measure the position of the cavity (right).

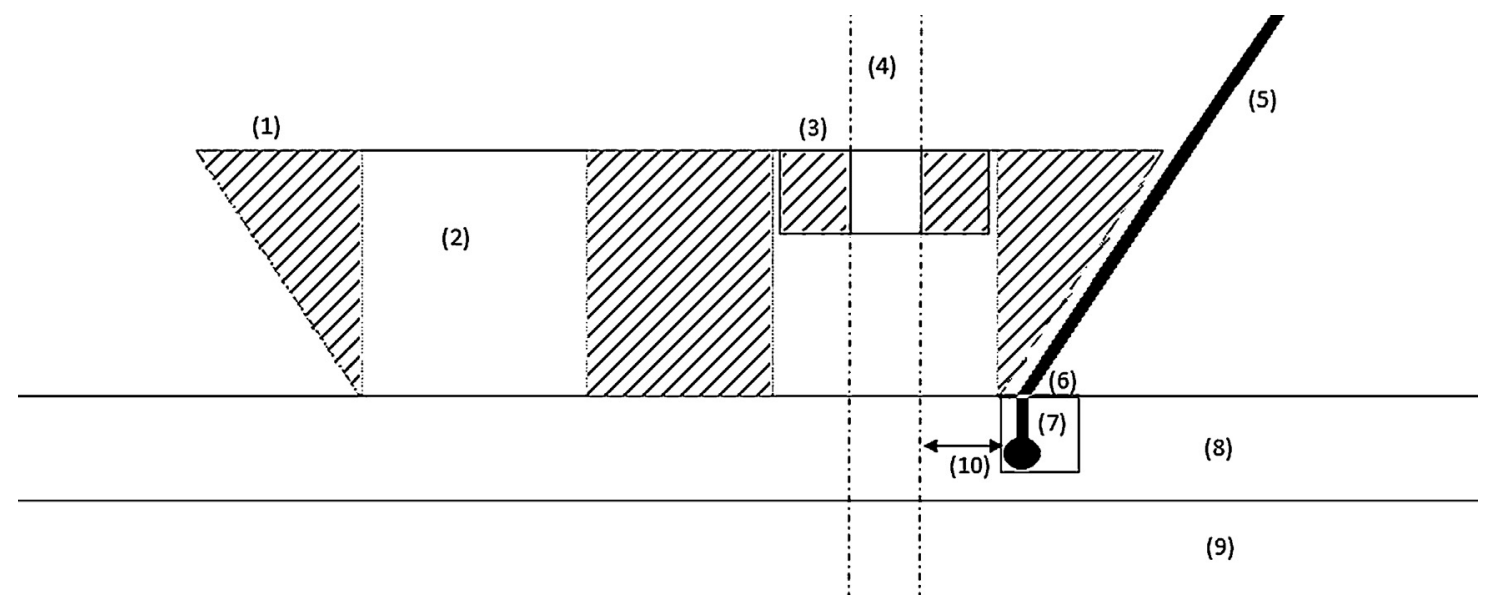

Fig. 2. Cross-section of the drill $(1)=$ surgical drilling guide, $(2)=$ drilling canal, (3) $=$ drill sleeve for the actual diameter of the drill, (4)=projected drilling path, (5) = thermocouple, (6) = insulation, (7)= bone chips, (8)= layer of cortical bone, (9)= layer of cancellous bone, and (10)= distance from the canal to be drilled ( $1.75 \mathrm{~mm}$ for the $2.0 \mathrm{~mm}$ drill, $1.50 \mathrm{~mm}$ for the $2.5 \mathrm{~mm}$ drill, $1.25 \mathrm{~mm}$ for the $3.0 \mathrm{~mm}$ drill, and $1.0 \mathrm{~mm}$ for the $3.5 \mathrm{~mm}$ drill).

\section{Results and Discussion}

The results of our measurements are shown in Table 1. Data from the drilling procedures were divided into groups by the following aspects: temperature of the irrigation fluid, method of drilling, and diameter of the drill. The values of the thermal changes in each group are shown in Figure 4 (supplementary data).

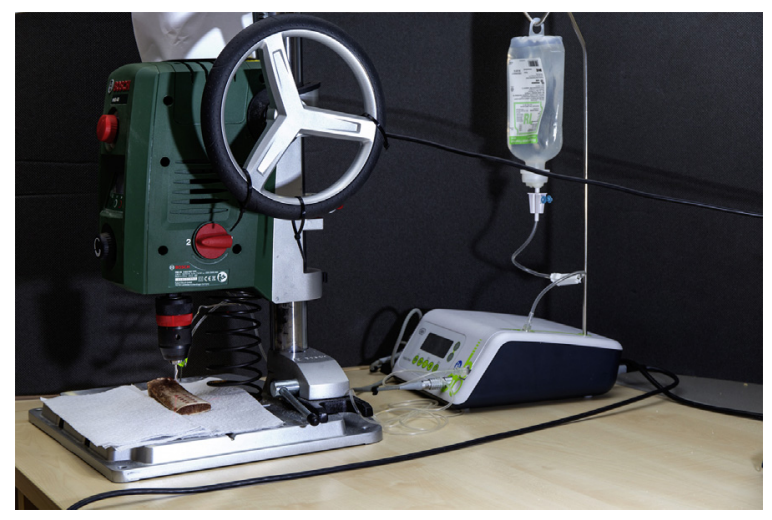

Fig. 3. The experiment.
There was a significantly smaller rise in temperature with freehand drilling with $10^{\circ} \mathrm{C}$ irrigation compared with the $20^{\circ} \mathrm{C}$ guided group $(\mathbf{p}=\mathbf{0 . 0 0 0}$ for all diameters $)$, regardless of the diameter of the drill. If freehand drilling with $10^{\circ} \mathrm{C}$ irrigation was compared with freehand drilling with $20^{\circ} \mathrm{C}$ irrigation, the difference between groups with the same drill diameter was significant $(\mathbf{p}=\mathbf{0 . 0 2 6}$ for $\mathbf{2 . 0} \mathbf{~ m m},(\mathbf{p}=\mathbf{0 . 0 0 0}$ for 2.5 and $3.0 \mathrm{~mm}$ ), with the exception of $3.5 \mathrm{~mm}$ drill diameter groups. When $10^{\circ} \mathrm{C}$ freehand irrigation was compared with $15^{\circ} \mathrm{C}$ guided irrigation, the difference was significant at $2.5(\mathbf{p}=\mathbf{0 . 0 0 5})$ and $3.0(\mathbf{p}=\mathbf{0 . 0 0 4}) \mathrm{mm}$, indicating the superior efficiency of lower temperature irrigation.

Guided drilling with $10^{\circ} \mathrm{C}$ irrigation also yielded a significantly lower temperature than the $20^{\circ} \mathrm{C}$ guided group ( $\mathbf{p}=\mathbf{0 . 0 0 0}$ for all diameters), regardless of the diameter of the drill. When the $10^{\circ} \mathrm{C}$ guided group was compared with the $20^{\circ} \mathrm{C}$ freehand group, the reduction in temperature was significantly more pronounced at all diameters except for $3.5 \mathrm{~mm}(\mathbf{p}=\mathbf{0 . 4 3 1}$ for $2.0 \mathrm{~mm}, \mathbf{p}=\mathbf{0 . 0 0 0}$ for 2.5 and $3.0 \mathrm{~mm}$, whereas $p=0.055$ for $3.5 \mathrm{~mm}$ and $p=0 . ? ?$ ). Finally, when the $10^{\circ} \mathrm{C}$ guided group was compared with the $15^{\circ} \mathrm{C}$ group, there were significantly lower rises in temperature at 2.5 $(\mathbf{p}=\mathbf{0 . 0 0 3})$ and $3.0(\mathbf{p}=\mathbf{0 . 0 0 0}) \mathrm{mm}$ compared with the guided technique, and at $3.0 \mathrm{~mm}$ compared with the freehand technique $(\mathbf{p}=\mathbf{0 . 0 2 5})$. 
Table 1

Mean rises in temperature for the examined groups showing the significant differences between groups with the same diameter of drill.

\begin{tabular}{|c|c|c|c|c|c|}
\hline Group & Diameter of the drill & $\begin{array}{l}\text { Guided/ } \\
\text { free-hand }\end{array}$ & $\begin{array}{l}\text { Temperature of } \\
\text { irrigation fluid } \\
\left({ }^{\circ} \mathrm{C}\right)\end{array}$ & $\begin{array}{l}\text { Mean }(\mathrm{SD}) \text { rise in } \\
\text { temperature }\left({ }^{\circ} \mathrm{C}\right)\end{array}$ & $\begin{array}{l}\text { Significant differences compared } \\
\text { with groups with the same drill } \\
\text { diameter (group number, } * \mathrm{p}<0.05 \text {, } \\
* * \mathrm{p}<0.01, * * * \mathrm{p}<0.001)\end{array}$ \\
\hline 1 & 2.0 & Free-hand & 10 & $0.11(0.61)$ & $17 *, 21 * * *$ \\
\hline 2 & 2.5 & Free-hand & 10 & $0.15(0.49)$ & $14 * *, 18 * * *, 22 * * *$ \\
\hline 3 & 3.0 & Free-hand & 10 & $0.71(0.96)$ & $15 * *, 19 * * *, 23 * * *$ \\
\hline 4 & 3.5 & Free-hand & 10 & $1.48(0.74)$ & $24 * * *$ \\
\hline 5 & 2.0 & Guided & 10 & $-0.04(1.15)$ & $17 *, 21 * * *$ \\
\hline 6 & 2.5 & Guided & 10 & $-0.02(0.80)$ & $14 * *, 18 * * *, 22 * * *$ \\
\hline 7 & 3.0 & Guided & 10 & $0.10(0.76)$ & $11 *, 15^{* * *}, 19 * * *, 23 * * *$ \\
\hline 8 & 3.5 & Guided & 10 & $1.40(0.58)$ & $24 * * *$ \\
\hline 9 & 2.0 & Free-hand & 15 & $0.66(0.52)$ & $21 * * *$ \\
\hline 10 & 2.5 & Free-hand & 15 & $1.13(0.51)$ & $18 *, 22 * *$ \\
\hline 11 & 3.0 & Free-hand & 15 & $1.75(0.65)$ & $7 *, 23 * *$ \\
\hline 12 & 3.5 & Free-hand & 15 & $1.89(0.70)$ & $24 * *$ \\
\hline 13 & 2.0 & Guided & 15 & $1.44(0.46)$ & - \\
\hline 14 & 2.5 & Guided & 15 & $1.85(0.71)$ & $2 * *, 6 * *$ \\
\hline 15 & 3.0 & Guided & 15 & $2.48(0.91)$ & $3 * *, 7 * * *$ \\
\hline 16 & 3.5 & Guided & 15 & $2.75(0.82)$ & - \\
\hline 17 & 2.0 & Free-hand & 20 & $1.74(0.73)$ & $1 *, 5^{*}$ \\
\hline 18 & 2.5 & Free-hand & 20 & 2.84 (1.19) & $2 * * *, 6 * * *, 10 *$ \\
\hline 19 & 3.0 & Free-hand & 20 & $3.11(1.14)$ & $3 * * *, 7 * * *$ \\
\hline 20 & 3.5 & Free-hand & 20 & $3.30(1.52)$ & - \\
\hline 21 & 2.0 & Guided & 20 & $2.56(0.92)$ & $1 * * *, 5 * * *, 9 * * *$ \\
\hline 22 & 2.5 & Guided & 20 & 3.45 (1.49) & $2 * * *, 6 * * *, 10 * *$ \\
\hline 23 & 3.0 & Guided & 20 & $4.35(1.36)$ & $3 * * *, 7 * * *, 11 * *$ \\
\hline 24 & 3.5 & Guided & 20 & $4.86(1.67)$ & $4 * * *, 8 * * *, 12 * *$ \\
\hline
\end{tabular}

In all cases the drilling speed was $1200 \mathrm{rpm}$ and the number of episodes of drilling was 20 . For the grouping numbers marked with one $*$, the exact p-values rounded to three decimal digits are the following: Group 1: 17* $(\mathrm{p}=0.026)$; Group 5: 17* $(\mathrm{p}=0.043)$; Group 7: 11* $(\mathrm{p}=0.025)$; Group 10: 18* $(\mathrm{p}=0.031)$; Group 11: $7 *(\mathrm{p}=0.025)$; Group 17: $1^{*}(\mathrm{p}=0.026)$ and $5^{*}(\mathrm{p}=0.043)$; Group 18: $10^{*}(\mathrm{p}=0.031)$.

Kondo et al. concluded that cold irrigation might lessen the rise in temperature caused by drilling, ${ }^{13}$ and the use of $10^{\circ} \mathrm{C}$ irrigation could be better at keeping the temperature under the necrotic threshold. ${ }^{12}$ Isler et al. concluded that the use of a $4{ }^{\circ} \mathrm{C}$ saline irrigation might result in better, quicker healing. ${ }^{22}$

Publications about the production of heat during guided surgery have so far studied only the use of normal saline at room temperature, and their findings may be summarised as follows. Misir et al. showed that a significantly higher peak in temperature could be measured during guided preparation of the implant site. ${ }^{6}$ In a study in which they used resin models there was no comparable difference when they used a flapless or a flap approach during guided surgery. ${ }^{7}$ An in vitro study by Migliorati et al. concluded that with proper irrigation, guided surgery can be as safe as the conventional method. ${ }^{8}$ Dos Santos et al. also showed that the rise in temperature stayed within the safe zone when a surgical guide was used. ${ }^{9}$ Finally, we have also shown that external irrigation can efficiently control the rise in temperature with the guided technique. ${ }^{10}$

A limitation of our study is that it was ex vivo. However, its strengths include the comparison of guided and freehand techniques, the use of saline solutions at different temperatures $\left(10^{\circ} \mathrm{C}, 15^{\circ} \mathrm{C}\right.$, and $\left.20^{\circ} \mathrm{C}\right)$, drilling throughout a whole sequence of four different drill diameters with the same axial load, and the quantity of external irrigation being well controlled.

\section{Conclusion}

The use of saline as irrigating fluid at $10^{\circ} \mathrm{C}$ meant that a significant reduction in peak temperature was achieved regardless of both the preparation technique of the site or the diameter of the drill. Considering our results that with irrigation at room temperature $\left(20^{\circ} \mathrm{C}\right)$ at a drilling speed of $1200 \mathrm{rpm}$, and a drill diameter of $3.5 \mathrm{~mm}$, near-necrotic temperatures may be reached, we suggest that the use of $10^{\circ} \mathrm{C}$ precooled irrigation fluid is a better way to control temperature.

\section{Conflict of Interest}

EV Jr. is the CEO, and EV is a consultant for and part-owner, of Dicom LAB Kft, Szeged, Hungary.

\section{Ethics statement/confirmation of patient permission}

No ethics approval was required as the research was done using samples of dead bone. 


\section{Acknowledgements}

We would like to thank Gabor Braunitzer for his support in preparing the text.

\section{Appendix A. Supplementary data}

Supplementary data associated with this article can be found, in the online version, at http://dx.doi.org/10.1016/ j.bjoms.2016.06.004.

\section{References}

1. Mishra SK, Chowdhary R. Heat generated by dental implant drills during osteotomy-a review: heat generated by dental implant drills. J Indian Prosthodont Soc 2014;14:131-43.

2. Eriksson AR, Albrektsson T, Albrektsson B. Heat caused by drilling cortical bone. Temperature measured in vivo in patients and animals. Acta Orthop Scand 1984;55:629-31.

3. Eriksson AR, Albrektsson T. Temperature threshold levels for heatinduced bone tissue injury: a vital-microscopic study in the rabbit. $J$ Prosthet Dent 1983;50:101-7.

4. Jung RE, Schneider D, Ganeles J, et al. Computer technology applications in surgical implant dentistry: a systematic review. Int J Oral Maxillofac Implants 2009;24(suppl):92-109.

5. Vercruyssen M, Laleman I, Jacobs R, Quirynen M. Computer-supported implant planning and guided surgery: a narrative review. Clin Oral Implants Res 2015;26(suppl 11):69-76.

6. Misir AF, Sumer M, Yenisey M, Ergioglu E. Effect of surgical drill guide on heat generated from implant drilling. J Oral Maxillofac Surg 2009;67:2663-8.

7. Jeong SM, Yoo JH, Fang Y, Choi BH, Son JS, Oh JH. The effect of guided flapless implant procedure on heat generation from implant drilling. $J$ Craniomaxillofac Surg 2014;42:725-9.

8. Migliorati M, Amorfini L, Signori A, Barberis F, Silvestrini Biavati A, Benedicenti S. Internal bone temperature change during guided surgery preparations for dental implants: an in vitro study. Int Oral Maxillofac Implants 2013;28:1464-9.
9. dos Santos PL, Queiroz TP, Margonar R, et al. Evaluation of bone heating, drill deformation, and drill roughness after implant osteotomy: guided surgery and classic drilling procedure. Int J Oral Maxillofac Implants 2014;29:51-8.

10. Boa K, Varga Jr E, Pinter G, Csonka A, Gargyan I, Varga E. External cooling efficiently controls intraosseous temperature rise caused by drilling in a drilling guide system: an in vitro study. Br J Oral Maxillofac Surg 2015;53:973-7.

11. Lundskog J. Heat and bone tissue. An experimental investigation of the thermal properties of bone and threshold levels for thermal injury. Scand J Plast Reconstr Surg 1972;9:1-80.

12. Sener BC, Dergin G, Gursoy B, Kelesoglu E, Slih I. Effects of irrigation temperature on heat control in vitro at different drilling depths. Clin Oral Implants Res 2009;20:294-8.

13. Kondo S, Okada Y, Iseki $\mathrm{H}$, et al. Thermological study of drilling bone tissue with a high-speed drill. Neurosurgery 2000;46:1162-8.

14. Davidson SR, James DF. Measurement of thermal conductivity of bovine cortical bone. Med Eng Phys 2000;22:741-7.

15. Yacker MJ, Klein M. The effect of irrigation on osteotomy depth and bur diameter. Int J Oral Maxillofac Implants 1996;11:634-8.

16. Katranji A, Misch K, Wang HL. Cortical bone thickness in dentate and edentulous human cadavers. J Periodontol 2007;78:874-8.

17. Augustin G, Davila S, Udiljak T, Vedrina DS, Bagatin D. Determination of spatial distribution of increase in bone temperature during drilling by infrared thermography: preliminary report. Arch Orthop Trauma Surg 2009;129:703-9.

18. Stelzle F, Frenkel C, Riemann M, Knipfer C, Stockmann P, Nkenke E. The effect of load on heat production, thermal effects and expenditure of time during implant site preparation - an experimental ex vivo comparison between piezosurgery and conventional drilling. Clin Oral Implants Res 2014;25:e140-8.

19. Sedlin ED, Hirsch C. Factors affecting the determination of the physical properties of femoral cortical bone. Acta Orthop Scand 1966;37:29-48.

20. Tehemar SH. Factors affecting heat generation during implant site preparation: A review of biologic observations and future considerations. Int J Oral Maxillofac Implants 1999;14:127-36.

21. Mohlhenrich SC, Modabber A, Steiner T, Mitchell DA, Holzle F. Heat generation and drill wear during dental implant site preparation: systematic review. Br J Oral Maxillofac Surg 2015;53:679-89.

22. Isler SC, Cansiz E, Tanyel C, Soluk M, Selvi F, Cebi Z. The effect of irrigation temperature on bone healing. Int J Med Sci 2011;8:704-8. 